\title{
PENINGKATAN KETERAMPILAN MEMBACA AWAL MELAUI METODE BERMAIN DENGAN MEDIA PUZZLE KATA PADA KELOMPOK B PAUD ISTIQOMAH SELUPU REJANG
}

\author{
Shinta Anggraini Rishantie \\ shintaanggraini608@gmail.com \\ Sri Saparahayuningsih \\ srisaparahayu@yahoo.co.id \\ Yulidesni \\ yulidesni@gmail.com
}

\begin{abstract}
The problem posed in this classroom action research is whether early reading skills in children in the PAUD group of Istiqomah Selupu Rejang can be improved through the method of playing using word puzzle media? This research was conducted with the aim to improve early reading skill in children of group B PAUD Istiqomah Selupu Rejang. Data collection techniques used are with the test techniques for children and observation for teachers. The data analysis technique used is with the average test technique. The results obtained are the improvements that occur in children's early reading skills by achieving an average value of 3.6 with the "good" criteria in cycle I and increasing with an average value of 4.5 with the criteria of "good" in cycle II. So it can be concluded that this research experience peningkatam but only increased quantitatively while qualitatively get a fixed result.
\end{abstract}

Keywords: Read early; Play method; Word Puzzle Media

\section{PENDAHULUAN}

Menurut UU. RI. NO. 20 Tahun 2003 BAB I Pasal 1 Ayat 14 "Pendidikan anak usia dini adalah suatu upaya pembinaan yang ditujukan kepada anak sejak lahir sampai dengan usia enam tahun yang dilakukan melalui pemberian rangsangan pendidikan untuk membantu pertumbuhan dan perkembangan jasmani dan rohani agar anak memiliki kesiapan memasuki pendidikan selanjutnya (dalam Syam, 2013:17).

Pada usia dibawah lima tahun (Balita) merupakan periode paling kritis atau biasa disebut masa emas (golden age) yang hanya datang satu kali seumur hidupnya dan tidak akan pernah terulang lagi. Tidak hanya pada usia balita, usia 5-8 tahun juga merupakan periode yang sangat kritis pada anak dan sangat membutuhkan stimulasi yang tepat untuk mengembangkan seluruh aspek perkembangannya. Pada usia emas ini anak harus mendapatkan stimulasi yang cukup/ baik, sesuai dengan kebutuhan. Stimulasi yang baik adalah stimulus yang dapat mengembangkan berbagai aspek perkembangan anak yang diantaranya yaitu: aspek kognitif, bahasa, agama-moral, sosial-emosional, motorik dan seni. Dari keenam aspek penting dalam kehidupan anak, aspek bahasa merupakan salah satu aspek penting yang harus ditingkatkan. Meningkatkan kemampuan bahasa ini bertujuan untuk mengembangkan kemampuan mendengar, berkomunikasi (baik secara lisan maupun tulisan), menambah perbendaharaan kata anak dan melatih keterampilan membaca dan menulis awal dengan simbol-simbol yang melambangkannya untuk persiapan membaca dan menulis. 
Oleh karena itu, peneliti melaksanakan penelitian tindakan kelas untuk meningkatkan keterampilan membaca awal anak melalui metode bermain dengan menggunakan media puzzle kata. Kelebihan dari puzzle kata ini adalah media ini merupakan media yang dikembangkan sendiri dan merupakan media inovatif yang dapat merangsang anak sehingga anak dapat berinteraksi dengan huruf dan kata, memberikan motivasi terhadap anak untuk lebih mengenal huruf dan kata sehingga dapat meningkatkan keterampilan membaca awal anak. Madyawati (2015:159) dalam bukunya mengatakan bahwa bermain dengan menggunakan media puzzle huruf (kata) merupakan salah satu pendekatan yang sesuai dengan karakteristik dan tumbuh kembang anak. Dengan bermain menggunakan puzzle huruf (kata) diharapkan dapat menarik minat anak sehingga anak dapat lebih termotivasi dalam mengikuti kegiatan untuk mengasah keterampilan membaca. Selain itu, bermain puzzle huruf (kata) relevan dengan konsep DAP (Developmentally Appropiate Practice) atau pendidikan yang sesuai dengan perkembangan anak.

Bermain, bermain itu sendiri merupakan suatu kegiatan yang di lakukan secara berulang-ulang untuk memperoleh kesenangan (Piaget dalam Madyawati, 2016:144). Shetty (dalam Madyawati, 2016:145) menganggap bahwa bermain sebagai suatu kegiatan yang mempunyai nilai praktis. Artinya, bermain digunakan sebagai media untuk menguatkan keterampilan dan kemampuan ter tentu pada anak. Misalnya, kemam puan berbahasa pada keterampilan membaca.

Permainan untuk perkembangan bahasa (membaca) anak terdapat 3 jenis yaitu: bermain aktiv, bermain pasif dan bermain fantasi. Dalam meningkatkan keterampilan membaca awal anak permainan yang digunakan adalah bermain pasif, karena bermain pasif merupakan salah satu kegiatan bermain yang tepat untuk meningkatkan keterampilan membaca.

Sedangkan media, Media adalah suatu komponen strategis penyam paian pembelajaran yang mengacu pada kegiatan apa yang dilakukan oleh si pengajar dan bagaimana peranan media dalam merangsang kegiatan belajar tersebut. (Trianto, 2013). Media terbagi menjadi 3 jenis yaitu (Bahan Ajar PPG dalam Ekayanti, 2010:5): media visual, audio dan audio visual. Dalam penelitian ini media yang digunakan adalah media yang termasuk ke dalam media visual yaitu media puzzle kata.

Menurut Tarigan (2015:12) dalam bukunya mengungkapkan terdapat dua aspek keterampilan membaca yaitu aspek yang bersifat mekanis (mechanical skisll) dan bersifat pemahaman (comprehension skills). Dalam penelitian ini aspek yang akan ditingkatkan adalah aspek mechanical skill. Aspek ini mencakup keterampilan menyebutkan huruf, membaca suku kata, membaca kata dan membaca kalimat sederhana 1 kalimat (3-5 kata). Sedangkan menurut pendapat yang diungkapkan oleh Madyawati (2016:147) dalam bukunya bahwa membaca awal dapat ditingkatkan melalui metode bermain yaitu metode bermain menggunakan media puzzle kata. Media ini merupakan inovasi yang dikembang kan dari media yang diungkapkan oleh Madyawati dalam bukunya yaitu media puzzle huruf.

Media puzzle kata dapat digunakan tidak hanya untuk mem baca melainkan dapat digunakan juga sebagai pengenalan huruf, suka kata, dan kata hingga kalimat sederhana. Sehingga diharapkan dari penerapan metode bermain dengan media puzzle kata ini dapat meningkatkan aspek keterampilan membaca awal terutama aspek mechanical skills (keterampilan mekanis). 
Sehingga dapat diambil kesimpulan bahwa tujuan penelitian ini adalah Tujuan dari pelaksanaan pene litian ini adalah untuk mengetahui apakah melalui media puzzle kata mampu meningkatkan keterampilan membaca awal anak.

\section{METODE}

Metode dalam penelitian ini ada lah menggunakan metode penelitian tindakan kelas (PTK). Penelitian ini dirancang sesuai model (Arikunto, 2009) yaitu dilaksanakan dengan tahapan perencanaan, pelaksanaan, observasi dan refleksi. Penelitian ini dilaksanakan di PAUD Istiqomah Selupu Rejang, khususnya pada kelompok B dan dilaksanakan dengan II siklus. Siklus I dilaksanakan selama 3 kali pertemuan (12 hari pelaksanaan) dan siklus II dilaksana kan selama 3 kali pertemuan (6 hari pelaksanaan). Teknik pengumpulan data yang digunakan adalah dengan teknik observasi dan tes. Kemudian teknik analisis data dengan statistik sederhana dengan rumus uji rata-rata mengadopsi rumus dari Aqib, dkk (2009:41).

Alat yang digunakan dalam penelitian ini adalah papan puzzle, kartu huruf, dan kartu gambar.

\section{HASIL DAN PEMBAHASAN}

Hasil yang diperoleh dari penelitian rata-rata keterampilan membaca awal anak memperolah rata-rata "Baik". Hal ini dibuktikan dengan peningkatan yang terjadi pada setiap pertemuan yang dilaksanakan. Pada siklus I pertemuan 1-3 memperoleh hasil rata-rata nilai keseluruhan 3,6 dengan kriteria "Baik" dan mencapai ketuntasan belajar $72 \%$. Dari hasil yang diperoleh pada siklus I maka peneliti melakukan refleksi dan melaksanakan tindakan selanjutnya pada siklus II untuk mencapai ketuntasan belajar 75\%. Pada siklus II pertemuan 1-3 memperoleh hasil rata-rata nilai keseluruhan 4,5 dengan kriteria "Baik" dan mencapai ketuntasan belajar $90 \%$. Sehingga dapat dilihat bahwa hasil dari penelitian meningkatkan keterampilan membaca awal melalui metode bermain dengan media puzzle kata berhasil mencapai ketuntasan belajar $75 \%$ dan meningkat secara optimal. Penelitian dilaksanakan dengan prosedur penelitian tindakan kelas, yang melalui empat tahap. Peneliti melaksanakan tahap demi tahap yaitu perencanaan, pelaksanaan, observasi dan refleksi untuk memperoleh hasil data yang diinginkan sesuai dengan kriteria ketuntasan belajar. Tetapi, dalam penelitian ini peningkatan yang dihasilkan adalah peningkatan secara kuantitatif sedangkan secara kualitatif memperoleh hasil yang tetap.

Berdasarkan uraian hasil pene litian di atas maka dapat disimpulkan bahwa kekurangan-kekurangan yang terjadi pada siklus I dapat teratasi melalui refleksi yang dilakukan oleh guru, sehingga pada siklus II terjadi peningkatan baik dari proses maupun hasil pembelajaran keterampilan mem baca awal anak. dari uraian hasil dan pembahasan ini sejalan dengan pen-dapat para ahli yaitu: Tarigan (2015: 12), mengatakan bahwa keterampilan membaca awal merupakan keteram pilan yang terdiri dari dua aspek utama yaitu: aspek mechanical skill (mengenal bentuk huruf, suku kata, kata dan kalimat sederhana) sebagai fokus dalam penelitian ini dan comprehension skill (bersifat pema haman) serta Madyawati (2016:145) dalam bukunya juga mengatakan bahwa kecerdasan berbahasa salah satunya membaca dapat ditingkatkan melalui kegiatan bermain. Contohnya, bermain Puzzle huruf dan dalam penelitian ini dikembangkan menjadi media Puzzle kata. Sehingga melalui metode bermain dengan media puzzle kata akhirnya keterampilan membaca awal aspek-aspek mechanical skill (mengenal bentuk huruf, membaca suku kata, membaca kata dan membaca kalimat sederhana yang terdiri dari 1 kalimat 3-5 kata) dapat mengalami peningkatan. 


\section{KESIMPULAN}

Keterampilan membaca awal anak kelompok B PAUD Istiqomah Selupu Rejang melalui metode bermain dengan media puzzle kata berhasil mengalami peningkatan. Media puzzle kata digunakan untuk menstimulasi keterampilan membaca awal anak seperti: membaca huruf, membaca suku kata, membaca kata dan mem baca kalimat sederhana.

Keterampilan membaca awal melalui metode bermain meng gunakan media puzzle kata mengalami peningkatan yang mencapai kriteria keberhasilan. Rata-rata nilai pada siklus I sebesar 3,6 dengan kriteria baik, meningkat pada siklus II yang mencapai rata-rata nilai 4,5 dengan kriteria baik.

Saran

Dari hasil penelitian yang telah dilaksanakan maka disarankan bagi guru untuk dapat menerapkan metode bermain dengan media puzzle kata untuk meningkatkan keterampilan membaca awal anak sebagai upaya dalam meningkatkan keterampilan berbahasa anak terutama aspek membaca awal.

\section{DAFTAR PUSTAKA}

Arikunto, Suharsimi. 2009. Penelitian Tindakan Kelas. Jakarta: Bumi Aksara.

Aqib, Zainal, dkk. 2009. Penelitian Tindakan Kelas. Bandung: Yrama.

Bachtiar, W Harsja. 2009. Media Pendidikan. Jakarta: Rajawali Pers.

Madyawati, Lilis. 2016. Strategi Pengembangan Bahasa Pada Anak. Jakarta: Kencana.

Tarigan, Henry Guntur. 2015. Membaca Sebagai Suatu Keterampilan Berbahasa. Bandung: CV. Angkasa.
Trianto. 2013. Desain Pengembangan Pembelajaran Tematik Bagi Anak Usia Dini TK/RA \& Anak Usia Kelas Awal SD/MI. Jakarta: KENCANA

Sumber:https://www.academia.edu/602842 3/MEDIA_PEMBELAJARAN_ANA K_USIA_DINI-PPG_UPI. Oleh: Ni Ekayati diunduh pada: 14 Januari 2017. 